\title{
EXAGGERATED CLIMATE WARMING ON THE ASSUMPTION OF UNIFORM ATMOSPHERIC $\mathrm{CO}_{2}$ CONCENTRATION
}

\author{
YANG, C. Y. ${ }^{1,4^{*}}-$ WANG, H. J. ${ }^{2 *}-$ ZHAO, S. X. ${ }^{3}-$ CUI, X. Y. ${ }^{1}-$ DENG, B. ${ }^{4}-$ LIU, X. P. ${ }^{5}$ \\ ${ }^{1}$ Aviation Meteorological Institute, 100085 Beijing, China \\ ${ }^{2}$ Department of Earth System Science, Institute for Global Change Studies, Tsinghua University \\ 100001 Beijing, China \\ ${ }^{3}$ Nanjing Weather Center, 210018 Nanjing, China \\ ${ }^{4}$ Harbin Flight Academy, 150001 Harbin, China \\ ${ }^{5}$ Institute of Atmospheric Environment, China Meteorological Administration, 100001 Beijing, China \\ *Corresponding authors \\ e-mail: cyyang0202@sina.com (C.Y. Yang),eerc2502@vip.sina.com (H.J.Wang) \\ phone: +86-136-4123-2199; fax: +86-451-8388-6961 \\ (Received 26 $6^{\text {th }}$ Jan 2018; accepted $10^{\text {th }}$ May 2018)
}

\begin{abstract}
Based on the observed atmospheric $\mathrm{CO}_{2}$ concentration data from the GAW (Global Atmosphere Watch) stations, we constitute a dynamical heterogeneous dataset of atmospheric $\mathrm{CO}_{2}$ concentration that varies monthly within the regional climate model domain around China referring to the heterogeneity of $\mathrm{CO}_{2}$ concentration in different economic regions and land use types. By running RegCM4-CLM3.5 climate model with this dataset, the climate warming rate was simulated and was compared with the control run with uniform $\mathrm{CO}_{2}$ concentration. The simulation study shows that $\mathrm{CO}_{2}$ greenhouse effect might have been aggrandized about $10 \%$ in the prevailing climate simulation due to improper assumption of uniform atmospheric $\mathrm{CO}_{2}$ concentration. The effect of $\mathrm{CO}_{2}$ itself (changing atmospheric transmissivity) is not the main reason for the reduction of temperature. The change of atmospheric $\mathrm{CO}_{2}$ concentration affects the $\mathrm{CO}_{2}$ partial pressure between air and interior of plant cells, and then the land plants adjust to this change by altering their stomatal conductance, which affects the water evapotranspiration from plant leaf to atmosphere consequently. On the one hand, this effect affects environmental temperature through the evaporation cooling, and on the other hand, the evaporated moisture alters the air humidity and influence the amount of low cloud by diffusion effect. This phenomenon is especially obvious in summer when the plants grow vigorously. The change of low cloud amount changes the short-wave radiation to the ground, which leads to the change of temperature.

Keywords: dynamic heterogeneous distribution of $\mathrm{CO}_{2}$, greenhouse effect, climate simulation, radiation budget and cloud feedback, physiological forcing effect
\end{abstract}

\section{Introduction}

Climate model is the most popular tool in routine climate prediction and climate change study because of its capability of handling the greenhouse effect quantitatively with various greenhouses gasses such as $\mathrm{CO}_{2}, \mathrm{CH}_{4}$ etc, which are closely related to human activities (Kiehl and Ramanathan, 1983; Szu-cheng and Liou, 1983; Smith et al., 2017). Unfortunately, the spatio-temporal heterogeneity of $\mathrm{CO}_{2}$ concentration in the atmosphere is not taken into consideration by the prevailing climate models, either global climate model (GCM) or regional one (RCM). For instance, in the prevailing GCM of CAM3.0, the volumetric mixing ratio of $\mathrm{CO}_{2}$ was assumed to 355 ppmv (Collins et al., 2004). While in the popular mesoscale model MM5, the mixing ratio of $\mathrm{CO}_{2}$ was 330 ppmv (Dudhia et al., 1998). The latest regional climate model RegCM3.1 and RegCM4.0 issued by ICTP 
(Abdus Salam International Centre for Theoretical Physics) has considered the $\mathrm{CO}_{2}$ concentration variation from 1750 to 2100 (Elguindi et al., 2010), but seasonal, monthly and even daily $\mathrm{CO}_{2}$ concentration variations were not taken into consideration. Besides, within the model domain, the $\mathrm{CO}_{2}$ concentration was still assumed to be uniform. The greenhouse effect plays the most important role in climate warming; the untrue atmospheric $\mathrm{CO}_{2}$ concentration in climate model should twist simulation (or prediction) accuracy.

China is a large country and covers several different climate zones. The vegetation types are diverse, and the source (or sink) of $\mathrm{CO}_{2}$ varies seasonally. The intense human activities and the uneven population density cause heterogeneous $\mathrm{CO}_{2}$ concentration distribution around China (Zhou et al., 2008; Zhao and Sun, 2014). Besides, the economic development level from east to middle and west of China is different, and the phenology from south to north of China is different as well, which causes $\mathrm{CO}_{2}$ concentration heterogeneities around China (Liu et al., 2011). The same is true for other big countries, particularly for the big developing countries.

The baseline atmospheric $\mathrm{CO}_{2}$ concentration and $\delta^{13} \mathrm{C}$ observation have proved that the annual and daily periodic variation of photosynthesis and respiration of the terrestrial ecosystems affects the $\mathrm{CO}_{2}$ concentration significantly (Liu et al., 2011). The large-scale ecological engineering construction around China, such as the Nature Forest Protection, Three-North Protection Forest Belt Construction, and Replacing Farm Land with Forest (or Grass) Engineering etc., changes $\mathrm{CO}_{2}$ source (or sink) structure and then $\mathrm{CO}_{2}$ concentration heterogeneities ( $\mathrm{Lin}$ and $\mathrm{Li}, 1998$ ).

Changing atmospheric $\mathrm{CO}_{2}$ concentration was the primary driver of global climate change even in the early Eocene (Anagnostou et al., 2016). So, the global network for $\mathrm{CO}_{2}$ concentration observation is set around the world gradually. The preliminary observation data shows that $\mathrm{CO}_{2}$ concentration is not uniform, but it shows significant temporal and spatial heterogeneity. The constant $\mathrm{CO}_{2}$ concentration used in the prevailing climate model is not proper, and there is a lack of work on climate simulation under heterogeneous atmospheric $\mathrm{CO}_{2}$ concentration at the moment. Therefore, we think it is necessary to study the possible climate changes that may arise from the heterogeneous distribution of $\mathrm{CO}_{2}$ concentration relative to the uniform distribution and to reveal the mechanism of these changes, which may provide a theoretical basis for improving the climate simulation. Based on this considerations, we collected $\mathrm{CO}_{2}$ concentration observation data around China, considering possible $\mathrm{CO}_{2}$ sources (or sinks) formation by social economic development factors, human activity and vegetation types etc., and configured a monthly varied dataset of heterogeneous $\mathrm{CO}_{2}$ concentration within the model domain, which was used to run the regional climate model RegCM4-CLM3.5 for 108 months from March 2000 to February 2009. The model outputs were compared with the control run in the same period and with constant $\mathrm{CO}_{2}$ concentration. On this basis, we discussed the regional climate effect caused by the heterogeneous $\mathrm{CO}_{2}$ concentration. Furthermore, according to the order of annual mean radiant flux, cloud feedback effect and $\mathrm{CO}_{2}$ physiological forcing effect, the possible mechanism of heterogeneous $\mathrm{CO}_{2}$ concentration affecting the temperature change is gradually explored from outside to inside.

\section{Materials and methods}

\section{The dataset formation}

According to the $\mathrm{CO}_{2}$ emission inventory issued by IPCC and the actual situation in China (Lin and Li, 1998; IPCC AR4, 2007), the factors that cause $\mathrm{CO}_{2}$ concentration 
heterogeneity include energy production, industrial emission, land use and land cover variation, and population density. The above factors are simplified to two categories: 1) factors related to industrial emission and economy development, 2) LULC variation related to agriculture and forestry. The details of dataset formation are illustrated in the Appendix after the article.

Combining with the temporal and spatial variation, monthly heterogeneous atmospheric $\mathrm{CO}_{2}$ concentration dataset in the model domain can be obtained (Fig. 1). The distributional pattern is reasonable as thinking about the plant phenological period, economic development level, and as well the population density etc. The $\mathrm{CO}_{2}$ concentration is high in the big city area and the East Coast of China. The annual variation with a high value in winter and lower value in summer is clear. The more details in winter, which is rather higher $\mathrm{CO}_{2}$ concentration occurrs in the forested area caused by respiration of the woody plants since the photosynthesis is weaker in this season. From May to July, however, $\mathrm{CO}_{2}$ concentration is lower in the land than that over the sea because most plants are in their vigorous growing season and assimilate more $\mathrm{CO}_{2}$. Statistics carried on within the model domain shows that the amplitude of yearly variation curve of the $\mathrm{CO}_{2}$ concentration varied for different LULC types (Fig. A3 in the Appendix). The correlation coefficient between the fitted curve and the observation data is 0.78 . The area-weighting averaged value of $\mathrm{CO}_{2}$ concentration in the model domain was $382.5 \times 10^{-6}$, a rather popular value of the present atmospheric $\mathrm{CO}_{2}$ concentration cited frequently by climate change researchers.
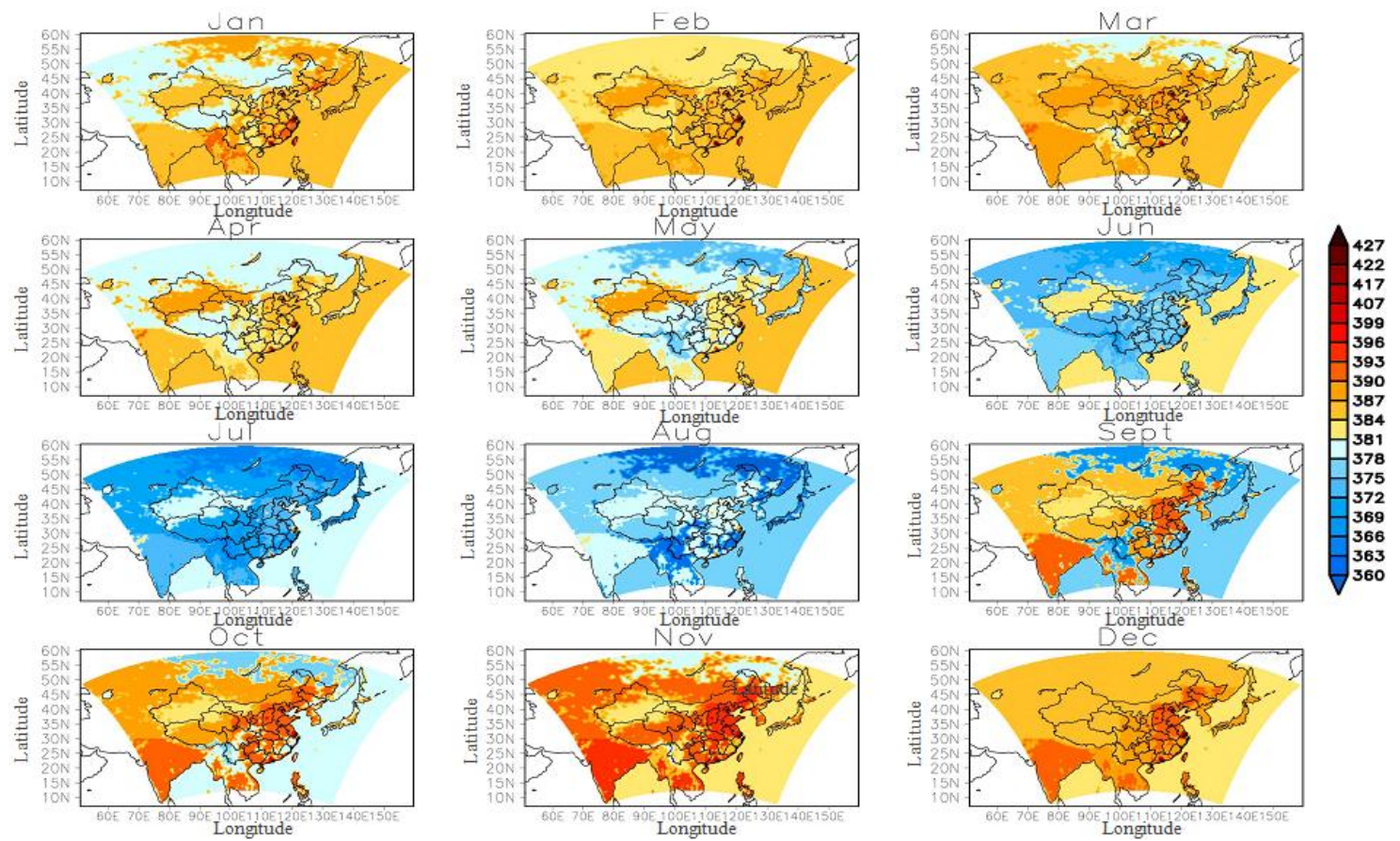

Figure 1. Monthly dynamical heterogeneous atmospheric $\mathrm{CO}_{2}$ concentration dataset within a regional domain around China (units: ppmv). The dataset is based on the baseline concentration data of atmospheric $\mathrm{CO}_{2}$ observed from the GAW stations, considering the heterogeneous distributional characteristics of $\mathrm{CO}_{2}$ concentration among different economic regions and land use types. The details of dataset formation are illustrated in the Appendix after the article 
We emphasize that the dynamic and heterogeneous $\mathrm{CO}_{2}$ concentration distributional pattern presented here is not perfect, nor is it the unique one. With the increasing atmospheric baseline stations, the temporal and spatial heterogeneity of $\mathrm{CO}_{2}$ concentration will be understood more clearly. It is just to remind on the dynamics and heterogeneity of the atmospheric $\mathrm{CO}_{2}$ concentration only.

\section{Model description and numerical simulations}

The regional climate model (RCM) used here is the version of RegCM4-CLM3.5 issued by ICTP in June 2010 (Elguindi et al., 2010). Compared with the previous version, RegCM4 incorporates a new land surface model of CLM3.5, which is from NCAR's Global Climate System Model CCM4 (Oleson et al., 2008). CLM3.5 is welcomed warmly by modelers because it can describe the land surface in more details, particularly in the carbon cycling process of land surface to reflect the feedback mechanism between the biosphere and climate system (Cox et al., 2000; Friedlingstein et al., 2006). Besides, RegCM4 also incorporates a sea surface temperature prediction module, which is essential to improve momentum flux in the sea-atmosphere interaction layer and is important to the present simulation study since one-third of the model domain is the ocean.

The horizontal grid is the same with the $\mathrm{CO}_{2}$ concentration dataset shown by Figure A.2 in the Appendix, vertically, the atmosphere is divided into 18 layers; the model top is set at $5 \mathrm{hPa}$ level. Physical parameterization scheme is as usual (Elguindi et al., 2010). A 12-grid exponential relaxing boundary is used in the lateral boundaries of the model domain. The land surface process is modeled by CLM3.5. The time integration step for land surface and upper atmosphere is 600 and $150 \mathrm{~s}$ respectively. Radiation module is updated every $30 \mathrm{~min}$; the lateral boundary condition is updated every 6 h using NCEP reanalysis data.

Besides the NECP reanalysis data, the OISST sea surface temperature (SST) data is also used in the model run. The model was run 110 months from January 1, 2000 to March 1, 2009. The first two-month data was removed since spin-up period and the left data of 108 months were used to analyze the effects of dynamic heterogeneous $\mathrm{CO}_{2}$ concentration on the climate change.

The model system was run for three $\mathrm{CO}_{2}$ concentration scenarios (Table 1).

Table 1. Three scenarios of atmospheric $\mathrm{CO}_{2}$ concentration

\begin{tabular}{c|c|c|c}
\hline $\begin{array}{c}\text { Name of } \\
\text { scenarios }\end{array}$ & $\begin{array}{c}\text { Atmosphere } \mathbf{C O}_{\mathbf{2}} \\
\text { concentration } \times \mathbf{1 0}^{-\mathbf{6}}\end{array}$ & $\begin{array}{c}\text { Distributional pattern of } \\
\mathbf{C O}_{2}\end{array}$ & Comments \\
\hline Sce1 & 280 & Uniform and constant & Pre-industry \\
\hline Sce2 & 382.5 & Uniform and constant & $\begin{array}{c}\mathrm{CO}_{2} \text { concentration at present } \\
\text { published by IPCC }\end{array}$ \\
\hline Sce3 & 382.5 & Dynamic and heterogeneous & $\begin{array}{c}\mathrm{CO}_{2} \text { concentration at present } \\
\text { published by IPCC }\end{array}$ \\
\hline
\end{tabular}

Sce1 represents the pre-industry stage when the atmospheric $\mathrm{CO}_{2}$ concentration is 280 ppmv, and Sce 2 is the averaged status of $\mathrm{Sce} 3$, with which a constant $\mathrm{CO}_{2}$ concentration of $382.5 \mathrm{ppmv}$ was used, Sce3 refers to a particular model run using a dynamic and heterogeneous atmospheric $\mathrm{CO}_{2}$ concentration dataset as mentioned above. The comparison study was carried out first between Sce1 and Sce2 (Sce2 minus Sce1, 
hereafter referred as EXP1) to test the model capability. Later on, we compared the difference of model outputs between Sce2 and Sce3 (Sce3 minus Sce2, hereafter referred as EXP2) to understand what the climate change will be if we use actual dynamic and heterogeneous $\mathrm{CO}_{2}$ concentration.

\section{Results}

\section{Comparison between Sce1 and Sce2 (EXP1)}

Figure 2 gives out averaged temperature difference at 2-m high of EXP1. As the atmospheric $\mathrm{CO}_{2}$ concentration increased from $280 \mathrm{ppmv}$ to $382.5 \mathrm{ppmv}$, the temperature increased (Fig. 2a) clearly, particularly in the continent, where the increment is more than $0.12^{\circ} \mathrm{C}$. Over the sea, it is less than $0.08{ }^{\circ} \mathrm{C}$, and the mean value in the domain is $0.11^{\circ} \mathrm{C}$. Considering the integrate time is about 10 years; this value is in good agreement with IPCC AR4's reports (2007). There are small areas in the Sea of Japan, northeast of China, and Bay of Bengal where temperature decrease, but the amount is small; in general, the $\mathrm{CO}_{2}$ increase does cause surface layer warming.

Figure $2 b$ is a latitude-high section showing vertical structure of temperature difference. The warming occurs in the lower part of the atmosphere below a level of $300 \mathrm{~h} \mathrm{~Pa}$. Above this level, the temperature difference shows negative. It had been reported that the greenhouse effect warms the troposphere and cool the stratosphere as compensation (Govindasamy and Caldeira, 2000). The model is acceptable in simulating greenhouse effect as atmospheric $\mathrm{CO}_{2}$ concentration increased.

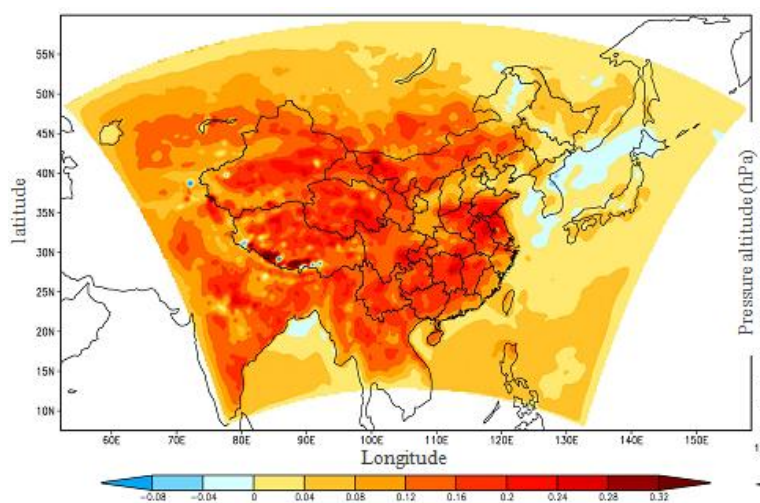

(a)

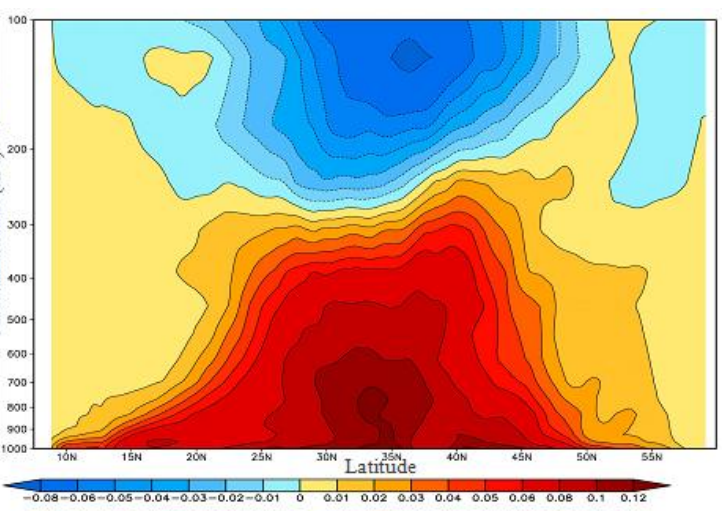

(b)

Figure 2. Averaged value of temperature difference in the EXPI (units: centigrade), (a) 2-m high temperature variation; (b) latitude-high section of the temperature difference

\section{Comparison between Sce2 and Sce3 (EXP2)}

Figure 3 shows the temperature difference of EXP2. As compared with the status of uniform $\mathrm{CO}_{2}$ concentration, the temperature was decreased in most areas of the model domain, which means we had aggrandized the greenhouse effect by assuming uniform and stable $\mathrm{CO}_{2}$ concentration in the climate model. The most significant temperature reduction happened in the middle, west and northeast of China's continent and the north of India. The decrement is $-0.03 \sim-0.15{ }^{\circ} \mathrm{C}$. There are also some areas where the temperature increased including middle part of Inner Mongolia, The triangle of BeijingTianjin-Tangshan and the Delta Economic Zone of Yangtze River, the southeast coast 
of China and the southeast of India etc. These areas are recognized as developed areas where the population density is high and human activities are intense. The average temperature of the whole domain is reduced by $-0.01{ }^{\circ} \mathrm{C}$. The White Paper of China's Policy and Action on Climate Chang reported that in average, the temperature was increased by $1.1{ }^{\circ} \mathrm{C}$ during the past 100 years (from 1908 to 2007) in China or $0.11{ }^{\circ} \mathrm{C}$ in every decade, the temperature reduction of $0.01{ }^{\circ} \mathrm{C}$ accounts for about $10 \%$ of this value. In other words, because of the uniform and stable $\mathrm{CO}_{2}$ concentration assumption in the climate model, the greenhouse effect of $\mathrm{CO}_{2}$ was aggrandized about $10 \%$ in the prevailing climate modeling.

The latitude-high section of the temperature difference in EXP2 was shown in Fig. 3b. An opposite shape occurred as compared with EXP1 (Fig. 2b). In the lower level below $250 \mathrm{hPa}$, the temperature decreased, while above this level, the temperature increased. The most significant temperature difference occurred in the middle latitude between $30-40^{\circ} \mathrm{N}$, and the values are rather small in the lower or higher latitude. Again, a negative feedback mechanism of the stratosphere to compensate the troposphere is clear.

The statistics were carried out for each LULC types (Table 2) in every economic zone in EXP2. The woodland and grassland show temperature reduction with larger values in the 2-class economic zone, and the urban and barren area show temperature increase except in the 3rd economic zone, where the value is -0.46 . Water body causes temperature reduction as well since it sequestrates $\mathrm{CO}_{2}$ from the atmosphere.

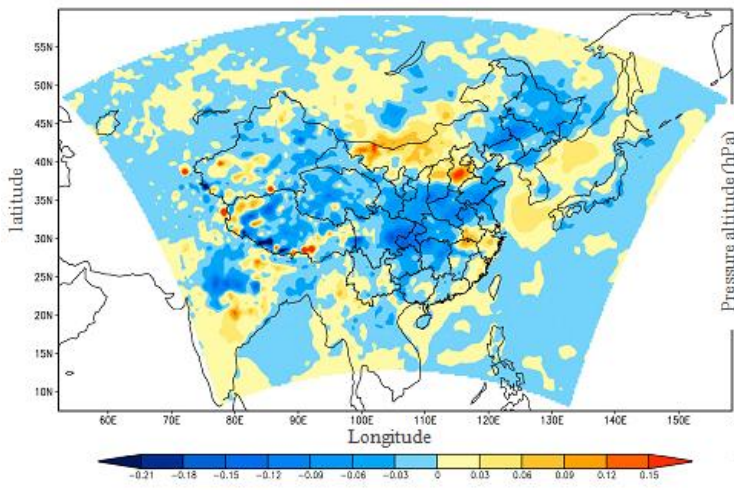

(a)

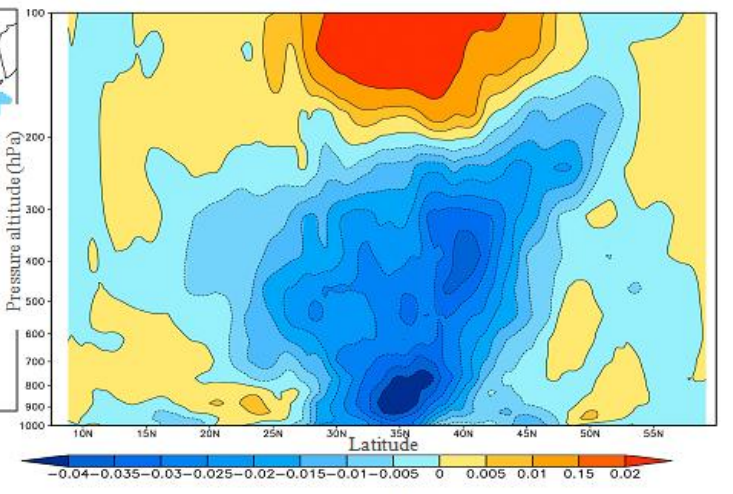

(b)

Figure 3. Averaged value of temperature difference in the EXP2 (units: centigrade), (a) 2-m high temperature variation; (b) latitude-high section of the temperature difference

Table 2. Average temperature reduction caused by dynamic and heterogeneous $\mathrm{CO}_{2}$ concentration in different economic regions and land use types $\left(\times 10-2{ }^{\circ} \mathrm{C}\right)$

\begin{tabular}{c|c|c|c|c|c}
\hline & Woodland & Grassland/Crop & Urban & Barren land (desert, permanent ice and snow) & Water \\
\hline 1-class & -0.48 & -1.27 & 1.41 & 2.56 & \\
\hline 2-class & -1.92 & -3.37 & 0.17 & 0.12 & \\
\hline 3-class & -0.46 & -0.53 & NaN & -0.46 & \\
\hline Water & & & & & -0.34 \\
\hline
\end{tabular}




\section{Discussion}

\section{Radiation budget}

Table 3 shows the comparison of various radiation elements, cloud amount and the temperature difference in EXP2. The statistics were carried out on clearly and cloudy day separately. Whenever the total cloud fraction is larger than 0.01 , it is classified as a cloudy day. Otherwise, it is a clear day.

Table 3. Bias of atmospheric radiative flux and cloud amount in the Exp2

\begin{tabular}{c|c|c}
\hline Items & Clear day & Cloudy day \\
\hline $\begin{array}{c}\text { Income shortwave }(\mathrm{SW}) \text { radiation flux at the top } \\
\text { layer of the model }\left(\times 10^{-2} \mathrm{~W} \cdot \mathrm{m}^{-2}\right)\end{array}$ & 0.4 & -2.0 \\
\hline $\mathrm{SW}$ radiation forcing by cloud & \multicolumn{2}{|c}{-2.4} \\
\hline Out longwave radiation $(\mathrm{OLR})$ in clear day & \multicolumn{2}{|c}{-0.8} \\
\hline Longwave radiation forcing by cloud & \multicolumn{2}{|c}{-1.6} \\
\hline Energy budget & -0.1 & -3.2 \\
\hline Surface longwave radiation flux $\left(\times 10^{-2} \mathrm{~W} \cdot \mathrm{m}^{-2}\right)$ & -2.0 & -3.8 \\
\hline Out longwave radiation at the $\mathrm{surface}$ & 0.5 & 1.2 \\
\hline Atmospheric radiation flux $\left(\times 10^{-2} \mathrm{~W} \cdot \mathrm{m}^{-2}\right)$ & \multicolumn{2}{|c}{ Total cloud amount 0.09} \\
\hline \multirow{2}{*}{ Cloud amount $\left(\times 10^{-2}\right.$ percentage $)$} & High cloud amount -0.04 \\
\cline { 2 - 3 } & \multicolumn{2}{|c}{ Middle and low cloud amount 0.13} \\
\cline { 2 - 3 }
\end{tabular}

In clear days, compared with Sce2, Sce3 gives a temperature increment of $0.1 \times 10^{-2}$ ${ }^{\circ} \mathrm{C}$, which is mainly caused by the increment SW radiation in the top layer $\left(0.4 \times 10^{-2}\right.$ $\left.\mathrm{W} / \mathrm{m}^{2}\right)$, reduction of OLR $\left(1.2 \times 10^{-2} \mathrm{~W} / \mathrm{m}^{2}\right)$ and the increase of atmospheric absorption of LR $\left(0.5 \times 10^{-2} \mathrm{~W} / \mathrm{m}^{2}\right)$, though the income surface SW radiation is reduced $\left(0.1 \times 10^{-2}\right.$ $\mathrm{W} / \mathrm{m}^{2}$ ). The atmospheric radiation penetration is not the main reason to cause the temperature reduction in Sce3.

In cloudy days, however, Sce 3 gives a temperature reduction of $-1.3 \times 10^{-2}{ }^{\circ} \mathrm{C}$, which is mainly caused by the reduction of income SW radiation $\left(-2.0 \times 10^{-2} \mathrm{~W} / \mathrm{m}^{2}\right)$, the negative energy budget $\left(-1.6 \times 10^{-2} \mathrm{~W} / \mathrm{m}^{2}\right)$, reduction of income $\mathrm{SW}$ radiation at the surface $\left(-3.2 \times 10^{-2} \mathrm{~W} / \mathrm{m}^{2}\right)$ and reduction of radiation forcing by cloud $\left(-2.4 \times 10^{-2} \mathrm{~W} / \mathrm{m}^{2}\right)$ though atmospheric absorption is increased $\left(1.2 \times 10^{-2} \mathrm{~W} / \mathrm{m}^{2}\right)$. The statistics for all cloudy day shows that high cloud amount reduced $-0.04 \%$ in Sce3, but the total cloud amount increased $0.09 \%$ on average and the middle and low cloud increased $0.13 \%$. The increased cloud can capture more LW radiation in the atmosphere, but it resists more shortwave radiation getting into the atmosphere, the integrated effect is to cause cooling (Andrews et al., 2012; Forster et al., 2015). So the cloud is the main reason to reduce greenhouse effect in dynamic and heterogeneous $\mathrm{CO}_{2}$ concentration scenario.

\section{Cloud amount variations}

The latest studies showed that temperature reduction is mainly due to cloud sensitivity to the $\mathrm{CO}_{2}$ concentration variation (Gregory and Webb, 2008; Andrews and Forster, 2008; Williams et al., 2008), and the cloud feedback mechanism is the main 
reason that causes difference among climate models (Bony et al., 2006; Caldwell et al., 2013). The cloud amount variation in EXP2 (Sce3 minus Sce2) is further analyzed by plotting all simulated examples to show the relationship among cloud amount, SW radiation and temperature reduction since high cloud is of less importance, and only the middle and low cloud data were used (Fig. 4). All the numerical grids either of temperature increase (red cross) or decrease (blue cross) are accounted though the former is of less number than the later. Figure $4 a$ shows that with increased cloud amount, both SW radiation and temperature reduction increased, the correlation coefficient reaches to -0.87 in temperature increased grid and -0.91 in temperature decreased grid. This means middle and low cloud increase is the main reason to reduce temperature in Sce3.

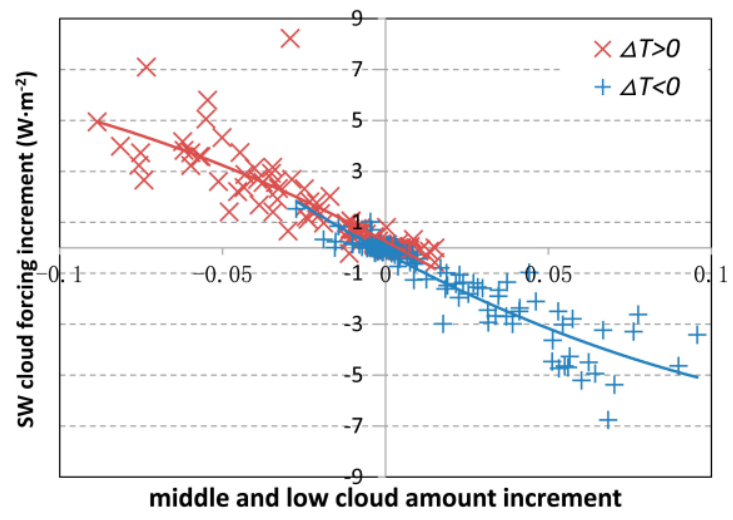

a

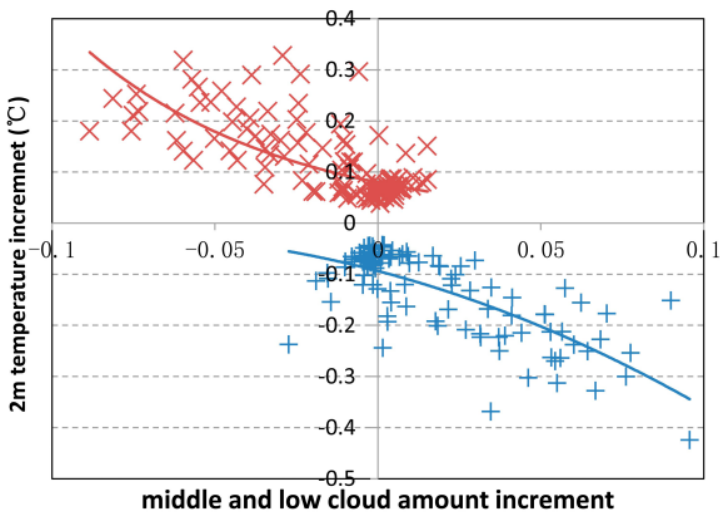

b

Figure 4. Scatter diagram showing the relationship between middle and low cloud amount increment and (a) shortwave radiative forcing increment and (b) $2 \mathrm{~m}$ high temperature reduction

The close relationship between cloud amount and temperature reduction can be illustrated by latitude-time section. Figure 5 also shows the temporal and spatial variability of cloud amount and the temperature difference between Sec2 and Sce3.

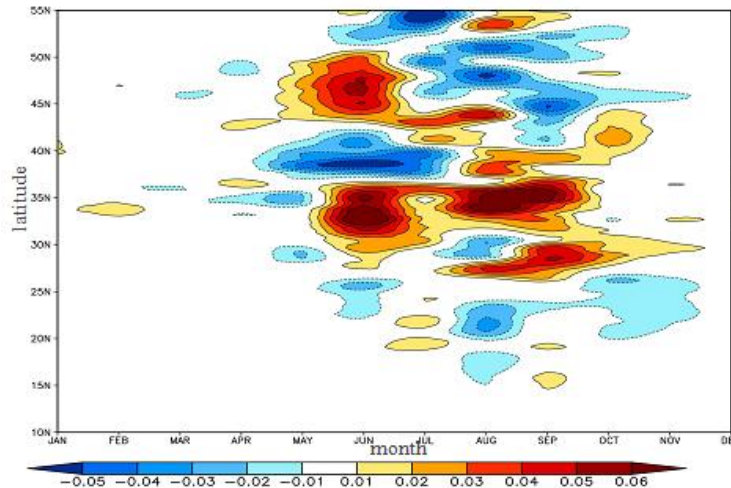

(a)

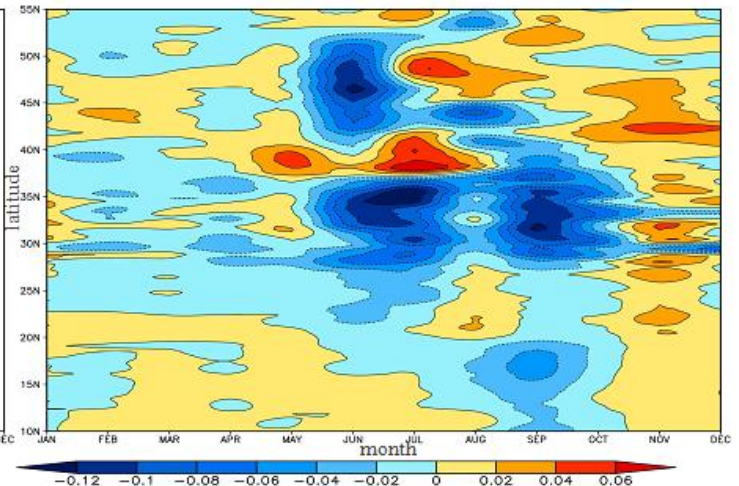

(b)

Figure 5. latitudinal mean-month section of (a) low cloud amount variation and (b) temperature difference (units: centigrade) in EXP2 
The most significant difference occurred in a middle latitude zone between $30-50^{\circ} \mathrm{N}$ during the summer from May to October. Wherever and whenever the middle and low cloud amount is increased (decreased), the temperature decreased (increase), and a negative correlation is clear.

\section{Physiological mechanism}

With the causality of $\mathrm{CO}_{2}$ concentration increasing and plant physiological adaptation being noticed widely, the consequence to the cloud formation, the radiation forcing and temperature reduction are also reported frequently (Lambert and Chiang, 2007; Lambert et al., 2011). Our simulation study shows that in summer, the $\mathrm{CO}_{2}$ concentration is rather lower, and the plant stomata conductance increases physiologically to adapt insufficient $\mathrm{CO}_{2}$ supply (Sellers, 1996; Sellers et al., 1997; Betts et al., 1997), which causes rather stronger plant transpiration and adds more water vapor into the atmosphere (Boucher et al., 2009; Joshi and Gregory, 2008; Abe et al., 2015). Moreover, this phenomena is more significant in the growing seasons of summer in the East Asian monsoon climate zone and in the middle latitude where the vegetation is dense. The plant transpiration cools the plant canopy and then the lower part of the atmosphere, which stimulates the formation of convective cloud (Joshi et al., 2008; Doutriaux-Boucher et al., 2009). In winter, however, most plants are in hibernation period, and the biological vigor is weaker, so plants show less sensitive to the outside $\mathrm{CO}_{2}$ concentration variation.

The present climate model and the relevant land surface model output affected by various plant physiological factors shows such ratiocination. Figure 6 illustrates regularity of some physiological parameters. Since most plants are vigorous in summer in the East Asian monsoon climate zone, the statistics were carried on the data in summer (June-November) only. The geographical difference can be classified into three regions based on Figure 6. To the south of $25^{\circ} \mathrm{N}$, the averaged stomata resistance (a) shows an increase, so the canopy transpiration (b), canopy evaporation (c) and 2-m high air humidity (d) show a decrease, which consequences the increase of absorbed radiation (e) and the 2-m high temperature (f). Between 25 to $40^{\circ} \mathrm{N}$, all the curve's phases were reversed, because of the increased stomata conductance, the canopy transpiration, canopy evaporation and 2-m high air humidity increased, which causes increased cloud amount and decreased absorbed radiation and 2-m high temperature. To the north of $40^{\circ} \mathrm{N}$, the curve tends to less amplified; it consists of the rather flat stomatal conductance.

In general, the lower $\mathrm{CO}_{2}$ concentration always occurs in the growing season and the densely vegetative area, and the plant responses with larger stomatal conductance, which leads to more canopy evaportranspiration, higher air humidity, and increment of the middle-low cloud. It is the main reason causing the temperature reduction in the growing season and vegetative areas. Since the vegetative area covers a rather larger portion of the model domain, the weighting averaged value of temperature reduced. This physiological mechanism can be extended to the diurnal variation of $\mathrm{CO}_{2}$ concentration as well, the periodic diurnal variation of $\mathrm{CO}_{2}$ concentration just like the yearly one. In the daytime, when the plant is in its vigorous period and the $\mathrm{CO}_{2}$ concentration is lower, which causes less greenhouse effect and mitigate warming, in the night. The $\mathrm{CO}_{2}$ concentration is high because of the plant respiration, but the greenhouse effect is weaker. Unfortunately, this paper has not incorporated diurnal 
heterogeneity of $\mathrm{CO}_{2}$ concentration into the modeling, but it is expected the temperature reduction could be even larger if it is considered.
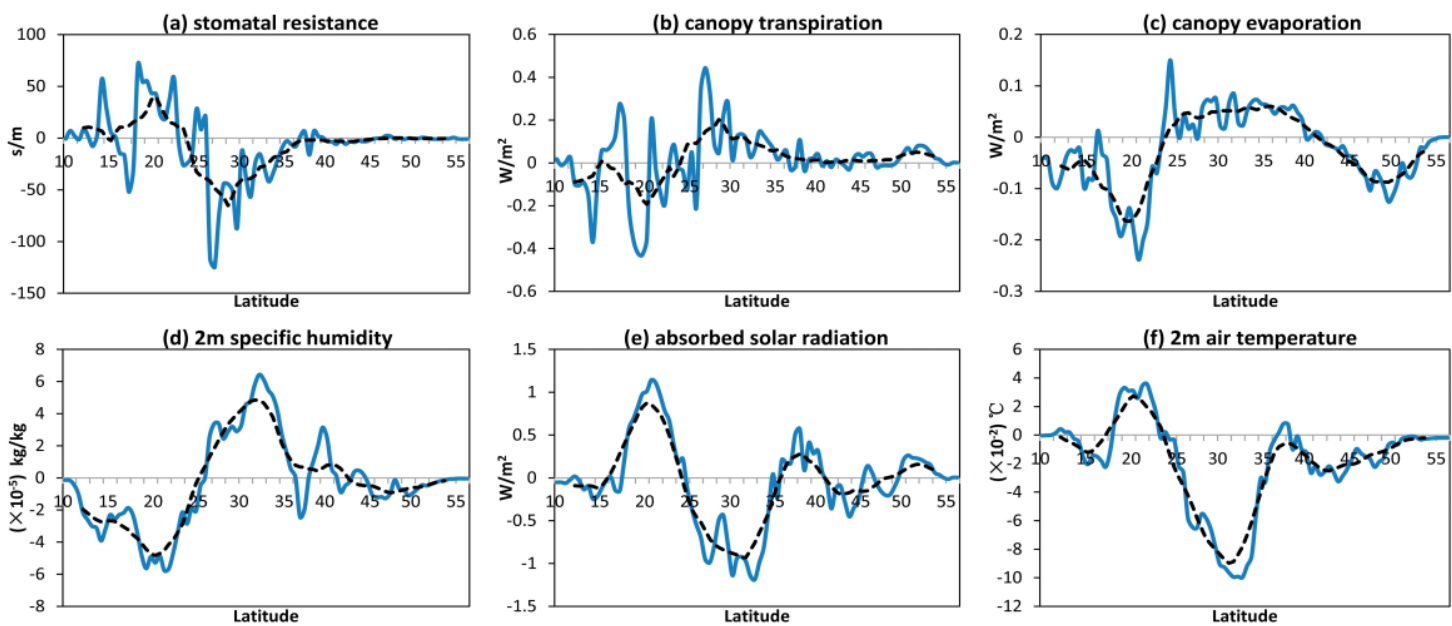

Figure 6. Zonal mean increment change of (a) stomatal resistance, (b) canopy transpiration, (c) canopy evaporation, (d) $2 \mathrm{~m}$ specific humidity, (e) absorbed solar radiation, $(f) 2 \mathrm{~m}$ high air temperature in the EXP2, the dashed line means the five-latitude moving average

For proving the physiological mechanism that dynamic and heterogeneous $\mathrm{CO}_{2}$ concentration causes less climate warming, a supplement model run was conducted, in which the land surface model CLM3.5 was replaced with BATS in EXP2 to remove any physiological effect in Sce3 since BATS uses constant plant parameters (Elguindi et al., 2010). The simulated temperature reduction is shown in Figure 7. Compared with Figure $3 b$, there is no significant temperature reduction in the troposphere in middle latitude, rather, there is a slight temperature increase, and the absolute values are much smaller as compared with Figure $3 b$.

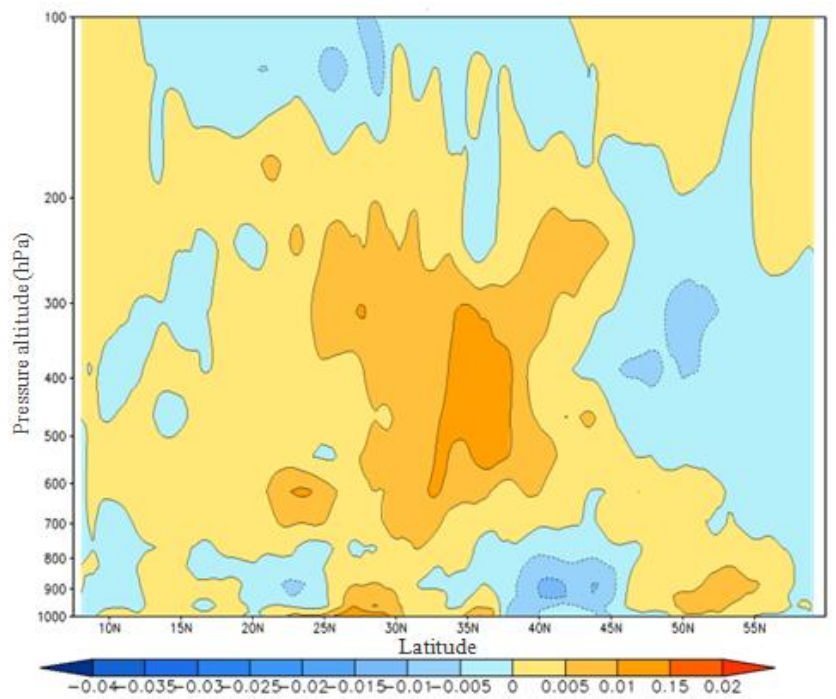

Figure 7. Latitude-high section of the temperature difference (units: centigrade) from the supplement run, same with EXP2 but replace the land surface model CLM3.5 with BATS in Sce3 


\section{Conclusions}

1) The uniform atmospheric $\mathrm{CO}_{2}$ concentration data used in the prevailing climate modeling is improper, the greenhouse effect of $\mathrm{CO}_{2}$ might be aggrandized about $10 \%$ because of the data flaw.

2) The simulation study reveals the main mechanism that dynamic and heterogeneous $\mathrm{CO}_{2}$ concentration reduces temperature increment. The variety of atmospheric $\mathrm{CO}_{2}$ concentration influences on the $\mathrm{CO}_{2}$ partial pressure between atomosphere and internal plant cell first. The land plants adapt to this change by altering their stomatal conductance, which affects the water evepotranspiration from plant canopy to the atmosphere, and the evaporated moisture increases air humidity then the formation and amount of low cloud. And the relevent evaporation cooling accelerates cloud formation as well. This mechanism is significant in summer when the most plants are in vigorous growing period and in the middle latitude where vegetation coverage is high.

3) With the increasing atmospheric baseline stations with $\mathrm{CO}_{2}$ concentration observation, the temporal and spatial heterogeneity of $\mathrm{CO}_{2}$ concentration will be clearer in the future, which should be used in the climate modeling to improve the accuracy of climate change prediction.

Because the dataset and model regions in this work are targeted at China, so the conclusion of the fourth part of the article (Analysis on the simulation results) is specific to the region of China. But the mechanism of the impact of the $\mathrm{CO}_{2}$ physiological effects on the climate change revealed in the fifth part of the article (Mechanism analyses) is universal. So we believe that in any region of the world, the climate effects that take into account the heterogeneity of $\mathrm{CO}_{2}$ concentration are similar, but the sensitivity of temperature change may be different. Therefore, it is very meaningful to carry out relevant research by using global climate model and $\mathrm{CO}_{2}$ concentration data of satellite detection.

In addition, it is expected that if the diurnal variation of atmospheric $\mathrm{CO}_{2}$ concentration is taken into consideration, the atmospheric $\mathrm{CO}_{2}$ concentration will be lower when the physiological activity of the plant is strong during the day, which may lead to the stronger physiological forcing effect and the greater amplitude of cooling, which is another issue worth studying.

Acknowledgements. This research was financially supported by the National Natural Science Foundation of China 41405135 .

\section{REFERENCES}

[1] Abe, M., Shiogama, H., Yokohata, T., Emori, S., Nozawa, T. (2015): Asymmetric impact of the physiological effect of carbon dioxide on hydrological responses to instantaneous negative and positive $\mathrm{CO}_{2}$ forcing. - Climate Dynamics 45: 1-12.

[2] Anagnostou, E., John, E. H., Edgar, K. M., Foster, G. L., Ridgwell, A. (2016): Changing atmospheric $\mathrm{CO}_{2}$ concentration was the primary driver of early Cenozoic climate. Nature 533(7603): 380-384.

[3] Andrews, T., Forster, P. M. (2008): $\mathrm{CO}_{2}$ forcing induces semi-direct effects with consequences for climate feedback interpretations. - Geophysical Research Letters 35(4): 222-256. 
[4] Andrews, T., Ringer, M. A., Doutriaux-Boucher, M., Webb, M. J., Collins, W. J. (2012): Sensitivity of an Earth system climate model to idealized radiative forcing. - Geophysical Research Letters 39(10): L10702.

[5] Betts, R. A., Cox, P. M., Lee, S. E., Woodward, F. I. (1997): Contrasting physiological and structural vegetation feedbacks in climate change simulations. - Nature 387(6635): 796-799.

[6] Bony, S., Colman, R., Kattsov, V., Allan, R., Bretherton, C. (2006): How well do we understand and evaluate climate change feedback processes. - Journal of Climate 19(15): 3445-3482.

[7] Boucher, O., Jones, A., Betts, R. A. (2009): Climate response to the physiological impact of carbon dioxide on plants. - Climate Dynamics 32(2-3): 237-249.

[8] Caldwell, P. M., Zhang, Y., Klein, S. A. (2013): CMIP3 Subtropical Stratocumulus Cloud Feedback Interpreted through a Mixed-Layer Model. - Journal of Climate 26(5): 16071625.

[9] Collins, W. D., Rasch, P. J., Boville, B. A., Hack, J. J., McCaa, J. R., Williamson, D. L., Kiehl, J. T. et al. (2004): Description of the NCAR Community Atmosphere Model (CAM 3.0). - National Center for Atmospheric Research Ncar Koha Opencat, tn-464+str: 14-21.

[10] Cox, P. M, Betts, R. A., Jones, C. D., Spall, S. A., Totterdell, I. J. (2000): Acceleration of global warming due to carbon-cycle feedbacks in a coupled climate model. - Nature 408(6809): 184-187.

[11] Doutriaux-Boucher, M., Webb, M. J., Gregory, J. M., Boucher, O. (2009): Carbon dioxide induced stomatal closure increases effective radiative forcing of climate via low cloud adjustment. - Geophysical Research Letters 36(2): 206-218.

[12] Dudhia, J., Gill, D., Manning, K., Wang, W., Bruyere, C. (1998): PSU/NCAR Mesoscale Modeling System tutorial class notes and users' guide (MM5 Modeling System Version 3). - Journal of Materials Processing Technology 77(1-3): 73-79.

[13] Elguindi, N., Bi, X. Q., Giorgi, F., Nagarajan, B., Pal, J., Solmon, F., Rauscher, S., Zakey, A. (2010): RegCM Version 4.0 User's Guide. - ICTP, Trieste, Italy.

[14] Forster, P., Sherwood, S., Bony, S., Boucher, O., Bretherton, C. (2015): Adjustments in the forcing-feedback framework for understanding climate change. - Bulletin of the American Meteorological Society 96(2): 217-228.

[15] Friedlingstein, P., Cox, P., Betts, R. A., Bopp, L., Bloh, W. V. (2006): Climate-carbon cycle feedback analysis: Results from the C4MIP model intercomparison. - Journal of Climate 19(14): 3337-3353.

[16] Govindasamy, B., Caldeira, K. (2000): Geoengineering Earth's radiation balance to mitigate $\mathrm{CO}_{2}$-induced climate change. - Geophysical Research Letters 27(14): 21412144.

[17] Gregory, J. M., Webb, M. J. (2008): Tropospheric adjustment induces a cloud component in $\mathrm{CO}_{2}$ forcing. - Journal of Climate 21(1): 58-71.

[18] IPCC AR4. (2007): Climate Models and Their Evaluation: Climate Sensitivity and Feedbacks - Cambridge University Press, Cambridge, pp. 629-639.

[19] Joshi, M. M., Gregory, J. M. (2008): The dependence of the land-sea contrast in surface climate response on the nature of the forcing. - Geophysical Research Letters 35(24): 851-854.

[20] Joshi, M. M., Gregory, J. M., Webb, M. J., Sexton, D. M. H., Johns, T. C. (2008): Mechanisms for the land/sea warming contrast exhibited by simulations of climate change. - Clim. Dyn. 30(5): 455-465.

[21] Kiehl, J. T., Ramanathan, V. (1983): $\mathrm{CO}_{2}$ radiative parameterization used in climate models: comparison with narrow band models and with laboratory data. - Journal of Geophysical Research 88(C9): 5191-5202.

[22] Lambert, F. H., Chiang, J. C. H. (2007): Control of land-ocean temperature contrast by ocean heat uptake. - Geophysical Research Letters 34(13): 173-180. 
[23] Lambert, F. H., Webb, M. J., Joshi, M. M. (2011): The relationship between land-ocean surface temperature contrast and radiative forcing. - Journal of Climate 24(13): 32393256.

[24] Lin, E. D., Li, Y. E. (1998): Global Climate Change and Greenhouse Gases Inventory Drawing. - China Meteorological Press, Beijing, China.

[25] Liu, Y. H., Wang, H. J., Zhang, X. Q. (2011): Climate Change and China Forestry Carbon Sink. - China Meteorological Press, Beijing, China.

[26] Oleson, K., Niu, G., Yang, Z., Lawrece, D., Thornton, P. (2008): Improvements to the Community Land Model and their impact on the hydrological cycle. - Journal of Geophysical Research Biogeosciences 113(G1): G01021.

[27] Sellers, P. J. (1996): Comparison of radiative and physiological effects of doubled atmospheric $\mathrm{CO}_{2}$ on climate. - Science 271(5254): 1402-1406.

[28] Sellers, P. J., Dickinson, R. E., Randall, D. A., Betts, A. K., Hall, F. G., Berry, J. A., Collatz, G. J., Denning, A. S., Mooney, H. A., Nobre, C. A., Sato, N., Field, C. B., Henderson-Sellers, A. (1997): Modeling the exchanges of energy, water, and carbon between continents and the atmosphere. - Science 275(5299): 502-509.

[29] Smith, K. L., Chiodo, G., Previdi, M., Polvani, L. M. (2017): No surface cooling over Antarctica from the negative greenhouse effect associated with instantaneous quadrupling of $\mathrm{CO}_{2}$ concentrations. - Journal of Climate 30. DOI: 10.1175/JCLI-D-17-0418.1.

[30] Szu-cheng, S. O., Liou, K. N. (1983): Parameterization of carbon dioxide $15 \mu \mathrm{m}$ band absorption and emission. - Journal of Geophysical Research 88(C9): 5203-5207.

[31] Williams, K. D., Ingram, W. J., Gregory, J. M. (2008): Time variation of effective climate sensitivity in GCMs. - Journal of Climate 21(19): 5076-5090.

[32] Zhao, J., Sun, Y. (2014): Spatial and temporal distribution characteristics of near-surface $\mathrm{CO}_{2}$ concentration over China based on GOSAT data. - Spie Proceedings Asia Remote Sensing and Modeling of the Atmosphere Oceans and Interactions V 9265(5). DOI: $10.1117 / 12.2074567$.

[33] Zhou, L. X., Liu, L. X., Zhang, X. C., Zhang, F., Yao, B. W. et al. (2008): Preliminary results on network observation of greenhouse gases at China GAW Stations. - Journal of Applied Meteorological Science 19(6): 641-644.

\section{APPENDIX}

\section{Details of the dataset formation}

The two-dimensional horizontal heterogeneity was assigned according to the different categories, and each category has its own monthly variation curve. The grid dataset of heterogeneous $\mathrm{CO}_{2}$ concentration suitable for numerical simulation is shown in Fig. A1. The domain center was set at $35^{\circ} \mathrm{N}, 105^{\circ} \mathrm{E}$, and the grid resolution was 60 $\mathrm{km}$. In addition, the longitudinal and latitudinal grid were 120 and 90 respectively. Lambert map project scheme was used in the model.

\section{Appendix 1}

\section{Economy development consideration}

The model domain was divided roughly into three different economic zones (Fig. A.1): 1) to the east of $110^{\circ} \mathrm{E}$ China, heavy industrial northeast of China, north of Indian plain (altitude is lower than $1000 \mathrm{~m}$ ), Burma, Vietnam and Philippine etc., the first category was classified as the most economically developed area where the population density is high, and $\mathrm{CO}_{2}$ emission is the highest; 2) The China's territory 
within $100 \sim 110^{\circ} \mathrm{E}$, and $20 \sim 38^{\circ} \mathrm{N}$, Japan, Korea peninsula, Taiwan and Hainan Island of China etc. This category was classified by the following considerations: the middle of China is less developed as compared with the east of China with rather backward science and technology. The $\mathrm{CO}_{2}$ emission of unit GDP is higher, but the population density is rather lower than that in the east of China. So the total $\mathrm{CO}_{2}$ concentration was classified as the second category, and Japan, Korea and Taiwan are with high population density. But compared with the first class area, the manufacture configuration is more reasonable, energy efficiency is high and the advanced high-tech utilization is more popular, so the $\mathrm{CO}_{2}$ emission from unit land is lower than those in the first class area; 3 ) The left area was classified as the third class, where the $\mathrm{CO}_{2}$ emission and $\mathrm{CO}_{2}$ concentration was assumed to be least, because the population is sparse and the economy is backward compared with above two classes. The water body itself is $\mathrm{CO}_{2}$ sink to absorb $\mathrm{CO}_{2}$ from the atmosphere. The $\mathrm{CO}_{2}$ emission over the water body by human activity was assumed to be zero, so it is classified separately as the fourth class. Based on the above assumption, the model domain area was classified with different $\mathrm{CO}_{2}$ concentration as shown in Figure Al.

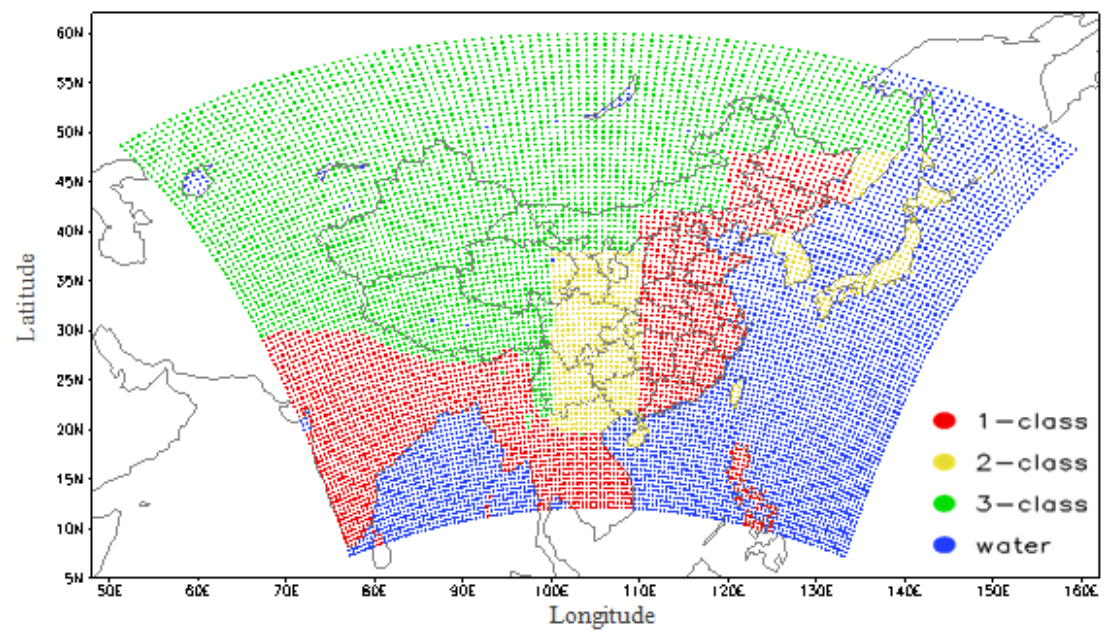

Figure A1. Distributional pattern of $\mathrm{CO}_{2}$ concentration classified according to economic development and population density

\section{Appendix 2}

\section{LULC variation consideration}

The LULC was classified into 5 categories to reflect their differences in $\mathrm{CO}_{2}$ sequestration capability according to the IPCC's relevant document (Busche, 2006). Those are forest, grass (or crop), urban, water, and barren land (include rock and Gobi, vegetation-free land, ice and snow). The original data was from the $1 \mathrm{~km}$ resolution LULC data derived from EOS/MODIS satellite information (hereafter called IGBP data). The $1-\mathrm{km}$ resolution data of the land surface model BATS (BiosphereAtmosphere Transfer Scheme; http://edcdaac.usgs.gov/glcc/glcc.html) was also used to compensate missing data in the mainland territory of China, which was from the NOAA's AVHRR dataset and commonly called GLCCD data. The 1-km resolution was then projected on the model domain to form a new dataset with a specific LULC type of the highest portion in each grid square only (Table Al), which is a benefit to differ the 
$\mathrm{CO}_{2}$ sequestration capability of different LULC types. Since the big city has a special function in $\mathrm{CO}_{2}$ emission, the grids are defined as city whenever the city portion in a grid square exceed $20 \%$. The LULC difference in the model domain is shown in Figure A2.

Table A1. Merging scheme of multi-types and high-resolution land use data based on the $I G B P$ and $G L C C D$

\begin{tabular}{|c|c|c|c|}
\hline ID & $\begin{array}{l}\text { LULC type } \\
\text { classification }\end{array}$ & IGBP (2004) & GLCC (1992 1993) \\
\hline 1 & Woodland & $\begin{array}{l}\text { Evergreen needle-leaf forests } \\
\text { Evergreen broadleaf forests } \\
\text { Deciduous needle-leaf forests } \\
\text { Deciduous broadleaf forests } \\
\text { Mixed forests } \\
\text { Closed shrublands }\end{array}$ & $\begin{array}{c}\text { Evergreen needle-leaf tree } \\
\text { Deciduous needle-leaf tree } \\
\text { Deciduous broadleaf tree } \\
\text { Evergreen broadleaf tree } \\
\text { Mixed Woodland } \\
\text { Forest/Field mosaic } \\
\text { Evergreen shrub }\end{array}$ \\
\hline 2 & Grassland/Crop & $\begin{array}{c}\text { Open shrublands } \\
\text { Woody savannas } \\
\text { Savannas } \\
\text { Grasslands } \\
\text { Croplands } \\
\text { Cropland/Natural vegetation mosaics } \\
\text { Permanent wetlands }\end{array}$ & $\begin{array}{l}\text { Crop/mixed farming } \\
\text { Short grass } \\
\text { Tall grass } \\
\text { Tundra } \\
\text { Irrigated Crop } \\
\text { Bog or marsh } \\
\text { Deciduous shrub }\end{array}$ \\
\hline 3 & Urban & Urban and built-up lands & \\
\hline 4 & Barren land & $\begin{array}{l}\text { Snow and Ice } \\
\text { Barren }\end{array}$ & $\begin{array}{c}\text { Desert } \\
\text { Semi-desert } \\
\text { Ice cap/glacier }\end{array}$ \\
\hline 5 & Water & Water bodies & $\begin{array}{c}\text { Inland water } \\
\text { Ocean } \\
\text { Water and Land mixture }\end{array}$ \\
\hline
\end{tabular}

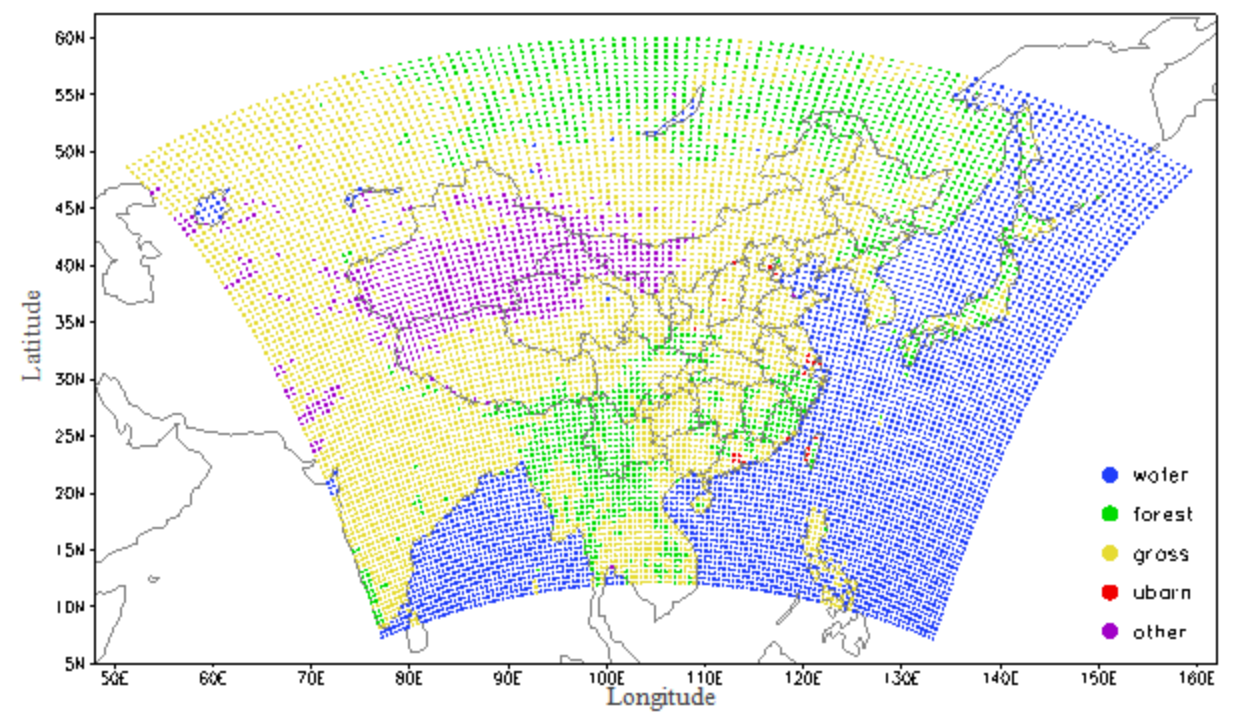

Figure A2. LULC classification for building the dynamical heterogeneous atmospheric $\mathrm{CO}_{2}$ concentration data 


\section{Appendix 3}

\section{Dynamics of the atmospheric $\mathrm{CO}_{2}$ concentration}

Intra-year variation of $\mathrm{CO}_{2}$ concentration for each LULC type was formed by referring to the baseline observation data, including the global atmospheric baseline stations, regional background stations, field and/or city temporal data logging (Wu et al., 2005; Cheng et al., 2003; Zhou et al., 2007; Wang et al., 2003). The data from the barren area (Waliguan Station) and ocean showed the smaller amplitude of $\mathrm{CO}_{2}$ concentration variation (Table A2), and these data were used to present the large-scale background data. While those from forest, grass and urban areas showed larger amplitude, and the $\mathrm{CO}_{2}$ concentration were affected by biological activities and local emission, which presents the local heterogeneity of $\mathrm{CO}_{2}$ concentration. In general, the $\mathrm{CO}_{2}$ concentration is higher in the east of China than in the west of China because of the intense human activity and higher population density.

Table A2. Information of referenced stations for atmospheric $\mathrm{CO}_{2}$ concentration

\begin{tabular}{|c|c|c|c|c|c|c|c|}
\hline $\begin{array}{l}\text { LULC } \\
\text { type }\end{array}$ & $\begin{array}{l}\text { Name of the } \\
\text { station }\end{array}$ & $\begin{array}{c}\text { Latitude } \\
(\mathbf{N})\end{array}$ & $\begin{array}{c}\text { Longitude } \\
\text { (E) }\end{array}$ & $\begin{array}{c}\text { Altitude } \\
/ \mathbf{m}\end{array}$ & $\begin{array}{l}\text { Vegetation } \\
\text { type }\end{array}$ & $\begin{array}{c}\mathrm{CO}_{2} \\
\text { concentration } \\
/ 10^{-6}\end{array}$ & $\begin{array}{c}\text { Data } \\
\text { collection } \\
\text { year }\end{array}$ \\
\hline \multirow{3}{*}{ Woodland } & $\begin{array}{l}\text { Longfen } \\
\text { Mountain }\end{array}$ & $44^{\circ} 44^{\prime}$ & $127^{\circ} 36^{\prime}$ & 310 & $\begin{array}{l}\text { Subsidiary } \\
\text { forest }\end{array}$ & $365 \pm 20$ & 2003 \\
\hline & $\begin{array}{l}\text { Changbai } \\
\text { Mountain }\end{array}$ & $44^{\circ} 08^{\prime}$ & $128^{\circ} 06^{\prime}$ & 740 & $\begin{array}{l}\text { Broad leaf- } \\
\text { Korea Pine } \\
\text { forest }\end{array}$ & $370 \pm 20$ & 2003 \\
\hline & $\begin{array}{l}\text { Suyukou in } \\
\text { Ningxia } \\
\text { Autonomous } \\
\text { Region }\end{array}$ & $38^{\circ} 44^{\prime}$ & $105^{\circ} 55^{\prime}$ & 1950 & $\begin{array}{c}\text { Northwest arid } \\
\text { area }\end{array}$ & $297 \pm 16$ & 2006 \\
\hline \multirow{5}{*}{$\begin{array}{l}\text { Grassland } \\
\text { /Crop }\end{array}$} & Linan & $30^{\circ} 18^{\prime}$ & $119^{\circ} 45^{\prime}$ & 130 & $\begin{array}{l}\text { Agricultural } \\
\text { mixing }\end{array}$ & $380 \pm 15$ & 2003 \\
\hline & Xinglong & $40^{\circ} 24^{\prime}$ & $117^{\circ} 30^{\prime}$ & 940 & shrubs & $375 \pm 15$ & 2000 \\
\hline & Haibei & $37^{\circ} 37^{\prime}$ & $101^{\circ} 17^{\prime}$ & 3400 & $\begin{array}{l}\text { Short grass } \\
\text { and wetland } \\
\text { shrubs }\end{array}$ & $315 \pm 20$ & 2004 \\
\hline & Wulanchabu & $41^{\circ} 47^{\prime}$ & $111^{\circ} 53^{\prime}$ & 1450 & $\begin{array}{c}\text { Typical } \\
\text { grassland }\end{array}$ & $330 \pm 18$ & 2006 \\
\hline & $\begin{array}{c}\text { Dashuiqugou of } \\
\text { Ningxia } \\
\text { Autonomous } \\
\text { Region }\end{array}$ & $38^{\circ} 39^{\prime}$ & $105^{\circ} 57^{\prime}$ & 1330 & $\begin{array}{l}\text { Hungriness } \\
\text { grassland }\end{array}$ & $335 \pm 20$ & 2006 \\
\hline \multirow{4}{*}{ Urban } & Beijing & $38^{\circ} 58^{\prime}$ & $116^{\circ} 22^{\prime}$ & 30 & Urban & $400 \pm 40$ & 2002 \\
\hline & Shang Dianzi & $40^{\circ} 39^{\prime}$ & $117^{\circ} 07^{\prime}$ & 290 & Sub-urban area & $375 \pm 25$ & 2003 \\
\hline & Huaian & $30^{\circ} 16^{\prime}$ & $118^{\circ} 59^{\prime}$ & 40 & $\begin{array}{l}\text { Middle-side } \\
\text { city }\end{array}$ & $400 \pm 30$ & 2006 \\
\hline & Hefei & $31^{\circ} 52^{\prime}$ & $117^{\circ} 17^{\prime}$ & 30 & $\begin{array}{l}\text { Reservoir } \\
\text { close to city }\end{array}$ & $390 \pm 30$ & 2008 \\
\hline
\end{tabular}




\begin{tabular}{c|c|c|c|c|c|c|c}
\hline & Wuxi & $31^{\circ} 25^{\prime}$ & $44^{\circ} 44^{\prime}$ & 10 & $\begin{array}{c}\text { Lake-side rural } \\
\text { area }\end{array}$ & $405 \pm 20$ & 2003 \\
\hline Other & Waliguan & $36^{\circ} 18^{\prime}$ & $100^{\circ} 54$ & 3820 & $\begin{array}{c}\text { Hungriness } \\
\text { grass }\end{array}$ & $375 \pm 5$ & 2004 \\
\hline Water & Ocean & & & & $\begin{array}{c}\text { Oceanic } \\
\text { boundary layer }\end{array}$ & $375 \pm 5$ & 2004 \\
\hline
\end{tabular}

Supposing the $\mathrm{CO}_{2}$ concentration of each LULC type varies regularly in a same economic zone, the average value of five LULC categories in four different economic zones are listed in Table A3. These values are used to feed the model at the initial state but vary as time of model integration (see next section).

Table A3. Model initial data of $\mathrm{CO}_{2}$ concentration for different economic regions and land use types

\begin{tabular}{c|c|c|c|c|c}
\hline & Woodland & Grassland/Crop & Urban & Barren land (desert, permanent ice and snow) & Water \\
\hline 1-class & 380 & 386 & 410 & 388 & \\
\hline 2-class & 378 & 384 & 405 & 386 & \\
\hline 3-class & 376 & 382 & 400 & 384 & \\
\hline Water & & & & & 383 \\
\hline
\end{tabular}

The dynamic characteristics of $\mathrm{CO}_{2}$ concentration were divided into two parts, the inter-annual variation and monthly variation in a specific year. The former followed the IPCC and reported values (ftp://crgd.atmos.uiuc.edu/pub/post-sres/A2-conc.txt) from 2000 to 2009. The later was assigned by thinking of growing period for different plants and the phenology in different climate zones. The monthly differential values of $\mathrm{CO}_{2}$ concentration from the average for five LULC types were listed and graphed in Figure A3.

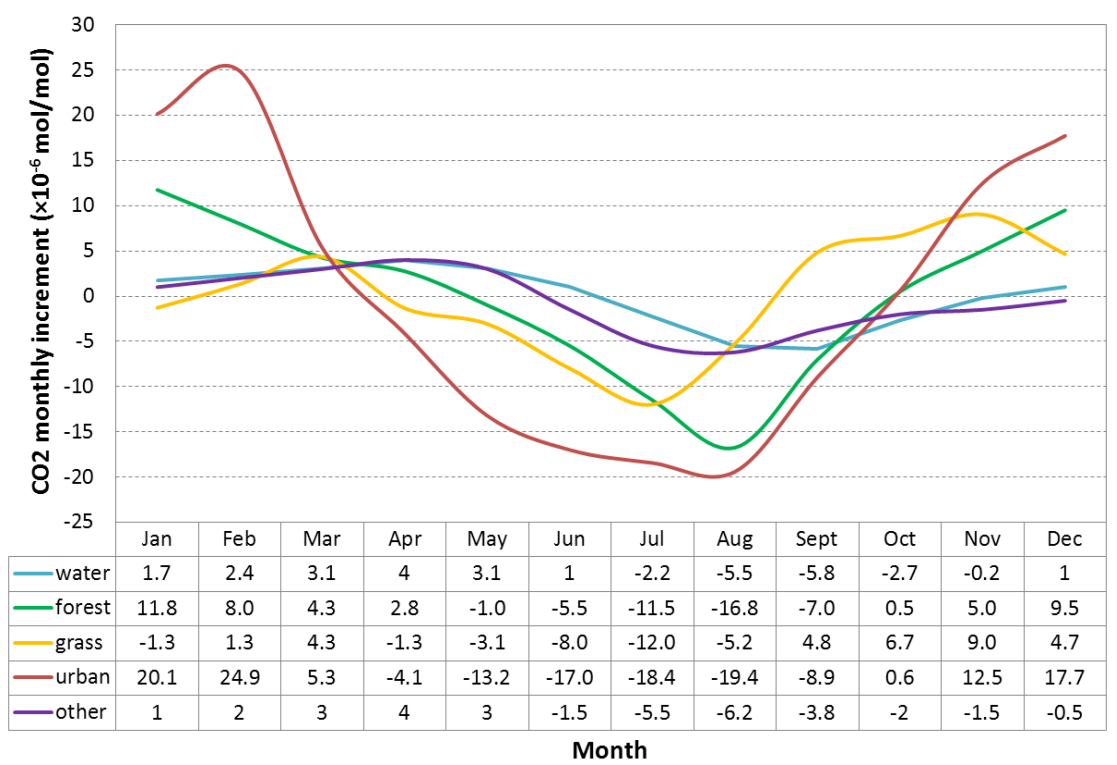

Figure A3. Monthly atmospheric $\mathrm{CO}_{2}$ concentration increment for different land use types 
The seasonal $\mathrm{CO}_{2}$ concentration variation is clear, and particularly in the urban area, forest and grass. The average value of the amplitude of $\mathrm{CO}_{2}$ concentration variation curve in the forest is about $10 \mathrm{ppmv}$, and those in urban area is $20 \mathrm{ppmv}$. The later reflects the intense human activity in the big cities such as house heating in winter, car running and other vehicles, over the water body and in the barren area, however, the amplitude is much smaller.

\section{APPENDIX REFERENCES}

[1] Busche, J. (2006): IPCC Draft Guidelines for National Greenhouse Gas Inventories. Vol. 3. Greenhouse Inventory Reference Manual. - IPCC, Busan Korea.

[2] Cheng, H. B., Wang, M. L., Wen, Y. P., Wang, G. C. (2003): Background concentration of atmospheric $\mathrm{CO}_{2}, \mathrm{CH}_{4}$, and $\mathrm{N}_{2} \mathrm{O}$ at MT. WALIGUAN and Xinglong in China. Quarterly Journal of Applied Meteorology 14(8): 402-409.

[3] Wang, C. K., Wang, Y. S., Liu, G. R. (2003): Characteristics of atmospheric $\mathrm{CO}_{2}$ variations and some affecting factors in urban area of Beijing. - Environmental Science 24(4): 13-17.

[4] Wu, J., Guan, D., Zhao, X., Han, S., Yu, G., Sun, X. (2005): $\mathrm{CO}_{2}$ concentration character in broad-leaved Korean pine Forest of Changbai Mountains. - Chinese Journal of Applied Ecology 16(1): 49-53.

[5] Zhou, L. X., Zhou, X., Zhang, X., Wen, Y., Peng, Y. (2007): Progress in the study of background greenhouse gases at Waliguan observatory. - Acta Meteorologica Sinica 65(3): 458-468. 